\title{
PELAKSANAAN MUTU PENDIDIKAN OLEH SUPERVISI PENDIDIKAN UNTUK TERCAPAINYA KUALITAS PENDIDIKAN NASIONAL
}

\author{
MHOREN PUSPITA SARI \\ Email : Mhorenpuspitasari25@gmail.com
}

\begin{abstract}
ABSTRAK
Pendidikan merupakan salah satu faktor yang sangat penting untuk kemajuan bangsa dan negara terutama untuk generasi muda agar tercapainya pendidikan indonesia ke arah nasional.Sebagai subsistem pendidikan nasional, maka pendidikan negeri maupun swasta seharusnya turut berkontribusi dalam membangun dan meningkatkan kualitas manusia Indonesia dengan menciptakan generasi yang berprestasi dalam ilmu pengetahuan,teknologi, dan mampu mengamalkannya dalam kehidupan sehari-hari.Untuk meningkatkan sistem pendidikan di Indonesia diperlukan pembimbing atau pembinaan dari supervior agar pendidikan di Indonesia dapat menuju ke arah yang lebih baik.

Dan untuk menigkatkan agar pendidikan itu bisa berkualitas diperlukanya orang-orang profesional.Guru sebagai pendidik di sekolah adalah salah satu faktor yang sangat penting,karna ketika guru dan siswa bisa berinteraksi dengan baik,maka guru itu di anggap sudah mampu menciptakan keadaan yang kondusif.Untuk mewujudkan pembelajaran ke arah nasional dibutkan sikap guru yang profesional,memiliki daya kreatif dalam proses pembelajaran.Agar pendidikan semakin membaik bukan hanya guru saja sebagi tenaga yang harus meningkatkan pembelajaran namun juga diperlukan lembaga pendidikan yang sikelola secara maksimal.

Agar pendidikan tercapai maka diperlukannya tujuan pendidikan nasional,yaitu untuk mengembangkan potensi peserta didik atau siswa untuk dapat berpikir rasional dan memiliki karakter mulia dalam kaitanya dengan nilai-nilai pancasila,yang menjunjung tinggi nilai kebenaran,kebaikan, keindahan.dan secara konstruktif dan kreatif untuk dapat bertanggung jawab untuk memajukanbangsa Indonesia dalam menyesuaikan diri dengan tuntunan masyarakat modren berdasarkan demokrasi dan keadilan.
\end{abstract}

Kata kunci: Pendidikan,Tujuan pendidikan Nasional

\section{Latar Belakang}

Pada saat sekarang ini kualitas pendidikan di Indonesia masih dikatakan sangatlah memprihatinkan.Hal ini terbukti dari kualitas guru,sarana belajr dan murid-muridnya.Adanya ketertinggalan yang dirasakan generasi muda di dalam dunia pendidikan, baik itu pendidikan formal maupun pendidikan informal.Ketertinggalan dari pendidikan Indonesia dapat kita lihat dari pendidikan negara lain.Pendidikan merupakan penopang dalam meningkatkan sumber daya manusia untuk peningkatan pendidikan 
Indonesia.Pada saat ini sumber daya manusia yang dimiliki masyarakat Indonesia sangatlah minim dan salah satu penyebabnya adalah kurangnya pendidikan di Indonesia.

Dapat kita lihat saja saat ini pendidikan Indonesia semakin hari kualitasnya semakin rendah seperti yang dijelaskan UBESCO. Berdasarkan Survey United Nations Educational, Scientific and Cultural Organization (UNESCO), terhadap kualitas pendidikan di Negara-negara berkembang di Asia Pacific, Indonesia menempati peringkat 10 dari 14 negara. Sedangkan untuk kualitas para guru, kulitasnya berada pada level 14 dari 14 negara berkembang.Salah satu faktor rendahnya kualitas pendidikan di Indonesia adalah karena lemahnya para guru dalam menggali potensi anak. Para pendidik seringkali memaksakan kehendaknya tanpa pernah memperhatikan kebutuhan, minat dan bakat yang dimiliki siswanya. Kelemahan para pendidik kita, mereka tidak pernah menggali masalah dan potensi para siswa. Pendidikan seharusnya memperhatikan kebutuhan anak bukan malah memaksakan sesuatu yang membuat anak kurang nyaman dalam menuntut ilmu. Proses pendidikan yang baik adalah dengan memberikan kesempatan pada anak untuk kreatif. Itu harus dilakukan sebab pada dasarnya gaya berfikir anak tidak bisa diarahkan.

Selain kurang kreatifnya para pendidik dalam membimbing siswa, kurikulum yan sentralistik membuat potret pendidikan semakin buram. Kurikulum hanya didasarkan pada pengetahuan pemerintah tanpa memperhatikan kebutuhan masyarakat. Lebih parah lagi, pendidikan tidak mampu menghasilkan lulusan yang kreatif. Ini salahnya, kurikulum dibuat di Jakarta dan tidak memperhatikan kondisi di masyarakat bawah. Jadi, para lulusan hanya pintar cari kerja dan tidak pernah bisa menciptakan lapangan kerja sendiri, padahal lapangan pekerjaan yang tersedia terbatas. Karena itulah kenapa kualitas pendidikan Indonesia sangat memprihatinkan.

Pendidikan yang seharusnya bisa menumbuhkan dan meciptakan generasi yangmemiliki daya ingat dan memiliki kecerdasan pada bidang-bidang yang di tekuninnya, namun pada saat ini pendidikan tidak sesuai dengan keinginan indonesia.Disinilah diperlukannya peran dan keikutsertaan pemerintah sebagai pengatur kurikulum, serta guru, dan supervisi pendidikan dalam meningkatkan kecerdasan anak dalam dunia pendidikan, agar tercapainya pendidikan yang berkualitas.

Berdasarkan uraian diatas, permasalahan dalam tulisan ini adalah (1) Bagaimana kondisi pendidikan yang segharusnya terjadi? (2) Bagaimana pelaksanaan pendidikan yang berkualitas? Tujuan tulisan ini adalah (1) untuk mengetahui pendidikan yang seharusnya, (2) untuk mengetahui pelaksanaan pendidikan yang berkualitas?

\section{PEMBAHASAN}

\section{Kondisi pendidikan yang seharusnya?}

Pendidikan indonesia yang memburuk sehaeusnya haeus mampu meningkatkan kecerdasan bangsa.Pelaksanan suatu pendidikan mempunyai fungsi inovasi,inisiasi,dan konversi.Oleh sebab itu untuk memperbaiki 
kehidupan berbangsa ,harus dimulai dari penataan segala aspek dalam pendidikan.salah satu aspek yang dimaksud adalah manajemen pendidikan.Pendidikan yang seharusnya sebenarnya harus mampu mencerdaskan generasi bangsa dan menciptakan generasi bangsa yang mampu dan memiliki generasi muda yang kretif. Namun pada saat ini kita lihat pendidikan yang seharusnya atau pendidikan yang baik itu sudah tidak jarang ditemukan,bahkan bisa dikatakan tidak layak dan rendah.Dibuthkannya proses pendidikan yang baik yaitu dengan memberikan kesempatan kepada anak untuk kreatif. Indonesia harus lebih memperhatikan sistem pendidikan Indonesia agar lebih terencana dan dapat menciptakan generasi yang hebat.

Pendidikan di Indonesia seharusnya bisa lebih melatih siswa untuk kreatif agar generasi bangsa ini bisa berpikir dan bertindak dalam melakukan hal.Selain itu untuk menjadikan pendidikan ke arah yang baik maka seharusnya lembaga pendiikan juga diharapkan mampu menjadi lembaga produksi sebagai penghasil bahan atau komponen dengan kualitas tertentu yang dituntut sesuai dengan pendidikan yang berkualitas. pemerintahan harus bisa meningkatkan profesional guru sebagi pendidik agar guru tidak hanya mampu membekali generasi dengan membaca-membaca tetapi membuat daya pikir siwa lebih berpikir maju.Sebagaimana yang diungkapkan oleh Sabandi (Sabandi, 2013) Seharusnya supervisi supervisi dilakukan dilakukan dalam dalam rangka menja min pembelajaran yang berkualitas.Artinya, bahwa keberhasilan pelaksanaan supervisi diukur dari peningkatan prestasi belajar diukur dari peningkatan prestasi belajar siswa.

\section{Pelaksanaan pendidikan yang berkualitas?}

Suatu bangsa akan maju jika pendidikanya baik dan berkualitas. Untuk menciptakan sesuatu yang berkualitas, dibuthkan pengorbanan dan usaha yang besar. Begitupun halnya dengan pendidikan, untuk mencapainya dibutuhkan usaha dan dana yang sangat besar demi menciptakan pencapaian atau hasil yang berkualitas.Sebaiknya pendidikan bangsa akan hancur apabila pendidikannya buruk

Salah satu Permasalahan pendidikan yang dihadapi oleh bangsa Indonesia adalah rendahnya kualitas pendidikan pada setiap jenjang dan satuan pendidkan, khususnya pendidikan dasar dan menengah. Berbagai usaha telah dilakukan untuk meningkatkan kualitas pendidikan, misalnya pengembangan kurikulum nasional dan lokal, peningkatan kompetensi guru melalui pelatihan, penggandaan buku dan alat pelajaran, pengadaan sarana dan prasarana pendidikan, serta peningkatan manajemen sekolah. Dengan demikian, berbagai indikator kualitas pendidikan belum menunjukkan peningkatan kualitas pendidikan yang cukup menggembirakan. Pada kenyataannya pendidikan bukanlah suatu upaya yang sederhana melainkan suatu kegiatan yang dinamis dan penuh tantangan. Setiap saat pendidikan selalu menjadi fokus perhatian dan bahkan tak jarang menjadi sasaran ketidak puasan karena pendidikan menyangkut kepentingan setiap orang.

Kesadaran tentang pentingnya pendidikan yang dapat memberikan harapan dan kemungkinan yang lebih baik di masa mendatang, telah mendorong berbagai upaya dan perhatian seluruh lapisan masyarakat terhadap setiap gerak dan langkah, dalam perkembangan dunia pendidikan. Pendidikan sebagai salah satu upaya dalam meningkatkan kualitas hidup, 
pada intinya bertujuan untuk memanusiakan manusia, mendewasakan, serta merubah prilaku dan meningkatkan kualitas hidup

Penyebab mengapa pendiikan Indonesia tidak berkualitas :

\section{Rendahnya Kualitas Sarana Fisik}

Untuk sarana fisik misalnya, banyak sekali sekolah dan perguruan tinggi kita yang gedungnya rusak, kepemilikan dan penggunaan media belajar rendah, buku perpustakaan tidak lengkap.

\section{Rendahnya Kualitas Guru}

Keadaan guru di Indonesia juga amat memprihatinkan. Kebanyakan guru belum memiliki profesionalisme yang memadai untuk menjalankan tugasnya sebagaimana disebut dalam pasal 39 UU No 20/2003 yaitu merencanakan pembelajaran, melaksanakan pembelajaran, menilai hasil pembelajaran, melakukan pembimbingan, melakukan pelatihan, melakukan penelitian dan melakukan pengabdian masyaraka

\section{Rendahnya Kesejahteraan Guru}

Rendahnya kesejahteraan guru mempunyai peran dalam membuat rendahnya kualitas pendidikan Indonesia. Dengan pendapatan yang rendah, terang saja banyak guru terpaksa melakukan pekerjaan sampingan.

\section{Rendahnya Prestasi Siswa}

Dengan keadaan yang demikian itu (rendahnya sarana fisik, kualitas guru, dan kesejahteraan guru) pencapaian prestasi siswa pun menjadi tidak memuaskan. Sebagai misal pencapaian prestasi fisika dan matematika siswa Indonesia di dunia internasional sangat rendah. Menurut Trends in Mathematic and Science Study (TIMSS) 2003 (2004), siswa Indonesia hanya berada di ranking ke-35 dari 44 negara dalam hal prestasi matematika dan di ranking ke-37 dari 44 negara dalam hal prestasi sains. Dalam hal ini prestasi siswa kita jauh di bawah siswa Malaysia dan Singapura sebagai negara tetangga yang terdekat.

\section{Kurangnya Pemerataan Kesempatan Pendidikan}

Kesempatan memperoleh pendidikan masih terbatas pada tingkat Sekolah Dasar. Data Balitbang Departemen Pendidikan Nasional dan Direktorat Jenderal Binbaga Departemen Agama tahun 2000 menunjukan Angka Partisipasi Murni (APM) untuk anak usia SD pada tahun 1999 mencapai 94,4\% (28,3 juta siswa). Pencapaian APM ini termasuk kategori tinggi.

\section{Rendahnya Relevansi Pendidikan dengan Kebutuhan}


Hal tersebut dapat dilihat dari banyaknya lulusan yang menganggur.

\section{Mahalnya Biaya Pendidikan}

Pendidikan bermutu itu mahal. Kalimat ini sering muncul untuk menjustifikasi mahalnya biaya yang harus dikeluarkan masyarakat untuk mengenyam bangku pendidikan. Mahalnya biaya pendidikan dari Taman Kanak-Kanak (TK) hingga Perguruan Tinggi (PT) membuat masyarakat miskin tidak memiliki pilihan lain kecuali tidak bersekolah.

\section{PENUTUP}

\section{Kesimpulan}

Berdasarkan pembahasan diatas dapat disimpulkan bahwa Pendidikan indonesia yang memburuk sehaeusnya haeus mampu meningkatkan kecerdasan bangsa.Pendidikan di Indonesia seharusnya bisa lebih melatih siswa untuk kreatif agar generasi bangsa ini bisa berpikir dan bertindak dalam melakukan hal.Selain itu untuk menjadikan pendidikan ke arah yang baik maka seharusnya lembaga.Kesadaran tentang pentingnya pendidikan yang dapat memberikan harapan dan kemungkinan yang lebih baik di masa mendatang, telah mendorong berbagai upaya dan perhatian seluruh lapisan masyarakat terhadap setiap gerak dan langkah, dalam perkembangan dunia pendidikan.Namun sebenarnya yang menjadi masalah mendasar dari pendidikan di Indonesia adalah sistem pendidikan di Indonesia itu sendiri yang menjadikan siswa sebagai objek, sehingga manusia yang dihasilkan dari sistem ini adalah manusia yang hanya siap untuk memenuhi kebutuhan zaman dan bukannya bersikap kritis terhadap zamannya.

\section{Saran}

Agar terciptanya pendidikan di Indonesia ke arah yang lebih baik diperlukan peran pemerintah,masyarakat, lembaga pendidikan, siwa dan supervisi lainya agar sistem dari pendidikan indonesia dapat berubah ke arah yang lebih baik.

\section{REFERENSI}

Ngalim Purwanto, Administrasi dan supervise pendidikan (Bandung : Remaja Rosdakarya, 1998), cet, ke-1-8, hal. 156.

Sabandi, A. (2013). Supervisi Pendidikan Untuk Pengembangan

Profesionalitas Guru Supervisi Pendidikan Untuk Pengembangan

Profesionalitas Guru Berkelanjutan Oleh: Pedagogi, Junal IImiah IImu 
Pendidikan, XVII(2), 1-9. Retrieved from

http://ejournal.unp.ac.id/index.php/pedagogi/article/view/4275/3345 